\title{
Late summer organic tomato production with heat tolerant tomato cultivars
}

\author{
Samantha Hilborn ${ }^{1,2}$, Michael Petersen ${ }^{1}$, Richard C. Pratt ${ }^{1}$ \\ ${ }^{1}$ Department of Plant and Environmental Sciences (PES) New Mexico State University, Las Cruces, NM, 88003 USA. \\ ${ }^{2}$ Present address: University of California-Davis, Davis, CA, 95616 USA
}

\section{*Corresponding author: ricpratt@nmsu.edu}

\section{Abstract}

Field production of organic fresh-market tomatoes in the U.S. Desert Southwest is desired by local producers and consumers. Tomato yield and fruit quality can be seriously impacted by heat stress (HS) and beet curly top virus (BCTV) infection of the main-season crop. We examined delayed planting of HS tolerant cultivars as a strategy for avoiding and mitigating these abiotic and biotic stressors. In 2016, seven putative HS tolerant cultivars, and one considered to be heat susceptible, were transplanted to the field in mid-summer to avoid peak populations of beet leafhopper (Circulifer tenellus), the vector of BCTV. In 2017, seven HS tolerant cultivars, one heatsusceptible, and two hot-set hybrid cultivars were transplanted in mid-summer. Fruit set was above $75 \%$ for most entries, including the heat-susceptible checks. Open-pollinated (OP) and hybrid cultivars exhibited a range of yields from 21.3 to $148.6 \mathrm{Mg} / \mathrm{ha}$ and fruit quality ratings from poor to excellent. The OP check 'Super Sioux' displayed consistently good yield and quality across years. The correlation between fruit set and yield was low $\left(R^{2}=0.29\right)$ and significant only at the 0.10 level $(P<0.09)$. The incidence of curly top (incited by BCTV infection) was less than $10 \%$ in both years, indicating mid-summer planting aided disease avoidance. 'Flamenco', the earliest variety, and two later maturing varieties 'Florida 91' and 'Skyway 687', are recommended for further evaluation. Mid-summer planting of small and medium-fruited tomato cultivars appears to be a viable option for organic fresh-market tomato production for the fall market in the Southwest USA.

Keywords: BCTV; curly top; heat stress; fresh market; fruit set; semi-arid crop production.

Abbreviations: BCTV_beet curly top virus; BER_blossom end rot; FS_fruit set; HS_heat stress; OP_open-pollinated; TSS_total soluble solids; TYMV_tomato yellow mosaic virus; TYLCV_tomato yellow leaf curl virus.

\section{Introduction}

Tomato (Solanum lycopersicum L.) is the leading vegetable in global production and most organic market gardeners in Europe and the United States value tomato as one of their most important crops (Horneburg and Myers, 2012). There is increasing demand for locally produced, fresh market, organic tomatoes and total U.S. production reached record levels in 2016 (5,018 ha). Between January 2013 and January 2018, the average retail price for round organic tomatoes (excluding Roma and cherry varieties) was $\$ 3.15$ per $\mathrm{kg}$-over $60 \%$ higher than their conventional counterparts, which sold for $\$ 1.96$ per $\mathrm{kg}$ (Baskins et al., 2019). Fresh tomatoes are a favorite of consumers, market producers, and home gardeners in the United States and New Mexico (Walker, 2014). Unfortunately, summer field production of tomatoes in the Southwest USA is precarious due to the detrimental impacts of both abiotic and biotic stresses on fruit yield and quality.

The most limiting abiotic stressor of irrigated field tomatoes in many desert regions is excessive heat during the summer (Cotter, 1978; Smith, 2016). Individual daytime high temperatures frequently exceed $38^{\circ} \mathrm{C}$ at elevations below 1524 $\mathrm{m}$ in New Mexico (NM Climate Center, 2018). The highest temperatures usually occur in late June and July-which often coincides with the flowering and fruit maturation period of main-season tomatoes planted in spring (Cotter, 1978). Pollination failure due to HS results in blossom-drop, which can greatly reduce yield by preventing fruit set (FS).

Multiple developmental, physiological, and metabolic processes are involved in the failure of FS in response to HS. Research indicates that early pollen development is the most susceptible developmental process (Bita et al., 2011). The detrimental effects of $\mathrm{HS}$ on pollen viability can begin at day temperatures as low as $27^{\circ} \mathrm{C}$ in susceptible tomato cultivars (Peet and Bartholomew, 1996). Moderate heat stress is defined as the prolonged presence of daily high temperatures reaching $32^{\circ} \mathrm{C}$ (Bita et al., 2011) and HS occurs when temperatures reach $35^{\circ} \mathrm{C}$, the temperature at which tomato flowers typically fail to pollinate (Mills and Johnson, 1988; Walker, 2014). It has been noted that providing partial shade during the afternoon is beneficial for FS (Smith, 2016; Walker, 2014), but this method of mitigation is impractical for most producers. 
There exists variation among tomato cultivars for HS tolerance, and some hot-set (or heat-set) modern hybrid cultivars are purported to maintain $\mathrm{FS}$ at day temperatures as high as $38^{\circ} \mathrm{C}$ and night temperatures above $24^{\circ} \mathrm{C}$ (Fontenot, 2016; Kemble et al., 2004). We define these elevated temperatures as extreme heat stress. Organic certified seed of most hot-set cultivars is currently unavailable.

Periodic flood irrigation, high temperatures, and low atmospheric humidity are strong drivers of fluctuations in plant water status during the crop cycle. In tomato, these fluctuations in water status may result in decreased fruit quality by causing fruit cracking (fruit splitting open) and blossom end-rot (BER), a disorder due to nutritional and physiological problems in susceptible cultivars. Fruit cracking and BER result in unsalable fruit, and cultivars with large fruit tend to be especially prone to these disorders (Matas et al., 2005). Small-fruited, i.e. cherry tomatoes are less susceptible to blossom-drop and fruit cracking (Dane et al., 1991).

Beet curly top virus (BCTV) is an important economic pathogen that incites yield-limiting disease (curly top) of multiple crops in the western USA and in Middle Eastern countries (Lehnhoff and Creamer, 2020). BCTV has a remarkably wide host range among crops and weeds in arid and semi-arid regions of both the New and Old Worlds (Chen and Gilbertson, 2016). It is a serious biotic threat to main season chile (Capsicum spp.) and tomato production in the Southwest. Curly top is particularly troublesome in small-scale production environments where there is an increased likelihood of infected reservoir hosts, e.g. winter annual weeds such as London rocket (Sisymbrium irio L.) and kochia (Kochia scoparia [L.] Schrad.) in the surrounding area (Blickenstaff and Traveller, 1979; Goldberg, 2001; Lehnhoff and Creamer, 2020). The virus is transmitted by a vector, the beet leafhopper (Circulifer tenellus). When overwintering host plants dry during the spring, the insect vectors seek new hosts-such as plants in agricultural fields. They may also persist during mid- and late summer where inoculum sources such as infected weeds or crop plants are present, because the leafhoppers can migrate back and forth between them (Chen et al., 2009). Insect vector populations often subside by the third week of July in southern New Mexico (Creamer et al., 2003).Young plants infected in the spring usually die rapidly. Plants infected after the seedling stage often survive-but they become yellow and stunted, and suffer reduced yields (Goldberg, 2001).

Unfortunately, cultivars with host-resistance to BCTV are unavailable or provide insufficient resistance (Heflebower et al., 2012). Techniques for managing BCTV have attempted to limit insect vector populations using pesticides, covering plants with a barrier to exclude the vector, or delaying planting until mid-summer to avoid the peak virus transmission period (Walker, 2014). The first two approaches involve added expense and labor (Heflebower et al., 2012) and the efficacy of delayed planting has not been studied.

The challenges presented by these abiotic and biotic stressors, and lack of cultivars with resistance to curly top, prevent many desert area producers and gardeners from planting tomatoes in spite of increasing demand. Successful mid-summer plantings could reduce the risk of yield and quality losses due to these stressors because high temperatures and insect vector populations usually start to subside by mid-summer. Delayed planting would also provide fruit for sale in the late- season market when price premiums are available for the producer (Kaiser and Ernst, 2016). Heat-tolerant cultivars could also help mitigate the periodic risk of heat stress during midto late summer and cultivars with appropriate maturity could also reduce the risk to ripening fruit posed by cold weather in the fall. No studies have yet evaluated the feasibility of lateseason organic field production in the semi-arid Southwest.

Our objective was to test the strategy of mid-summer planting of tomato to avoid the peak of high temperatures and insect vector populations that cause reduced FS and incite curly top, respectively. We also wished to identify tomato cultivars of appropriate maturity that were capable of producing small to medium sized fruit of good quality. We selected primarily OP cultivars because many organic producers prefer to save the seed of heirloom and public-sector OP varieties. Some consumers prefer heirloom varieties and organic growers may find commercial hybrids to be unavailable or expensive-and one of the goals of organic farming is to minimize external inputs (Horneburg and Myers, 2012). In the 2017 experiment, we included hybrids and sampled additional cultivar diversity for maturity, fruit size, and heat stress tolerance to expand our inference space and enhance the probability of identifying suitable cultivars that could be recommended for late-season organic production.

\section{Results}

\section{Marketable fruit yield}

We observed overall marketable yields of 57,808 and 41,785 $\mathrm{kg} / \mathrm{ha}$ in 2016 and 2017, respectively. Among the small-fruited cultivars in 2016, 'Black Mauri' had the highest yield and 'Flamenco' had the highest yield in 2017-in contrast to its below average yield in 2016 (Tables1 and 2). Among the cultivars producing medium sized fruit, 'Super Sioux' was the top yielder during both years. The hybrid cultivar 'Skyway 687' was the only large-fruited cultivar tested, and its yield was equivalent to other medium-sized cultivars and superior to that of the lowest yielding cultivars 'Homestead 24F' and 'Bella Rosa' in 2017.

\section{Fruit set}

In 2016 and 2017, almost all cultivars exhibited high percentages of FS (75\% or above) (Tables 1 and 2). Two cultivars, 'Arkansas Traveler' and 'Homestead 24F', had FS percentages below $75 \%$. There were no significant differences between cultivars in either year. The check cultivars 'Super Sioux' and 'Flamenco' consistently displayed FS percentages over $75 \%$ across years. The plants were exposed to HS during the flowering period, with multiple periods of maximum temperatures above $35^{\circ} \mathrm{C}$ during mid- to late summer of both years (Fig. 1). Extreme HS was also experienced, especially during the vegetative period and early flowering period in 2016. The overall correlation between FS and yield was low $\left(R^{2}\right.$ $=0.29)$ and significant only at the 0.10 level $(P<0.09)$. The susceptible check cultivars 'Moneymaker' and 'Longkeeper', which were previously reported to suffer low FS in response to HS (Bita et al., 2011; Dane, 1991), displayed FS values comparable to those of the cultivars with the highest FS value. 


\section{Curly top}

The total incidence of curly top was $9 \%$ in 2016, and $4 \%$ in 2017.

\section{Days to maturity}

'Flamenco' was the earliest maturing cultivar in both years (Tables 1 and 2). In 2016, it was six days earlier than 'Black Mauri' but it was not statistically different from 'Black Mauri', 'Super Sioux', and 'Nichol's'. In 2017, 'Flamenco' was significantly earlier maturing than all of the other cultivars. The latest maturing cultivars were 'Homestead' (97 days) in 2016 and 'Tribute' (101 days) in 2017. All cultivars took longer to mature than the average days to maturity indicated in their catalog descriptors.

\section{Fruit weight}

In 2016, most of the fruit were small (under $60 \mathrm{~g}$ ). 'Super Sioux' and 'Homestead' were the only two medium-fruited cultivars, and they produced fruit with significantly higher weights than the other cultivars. In 2017, most of the fruit were of medium weight (60 to $280 \mathrm{~g}$ ), except for 'Skyway 687', which yielded large fruit over $300 \mathrm{~g}$ in weight.

\section{Overall fruit quality}

Of the eight cultivars tested in 2016, four were perceived by the authors to have good overall fruit quality: 'Super Sioux', 'Chico III', 'Flamenco', and 'Homestead'. The other varieties were considered to have fair quality. The preferred cultivars in 2017 for overall fruit quality were 'Bella Rosa', 'Florida 91', and 'Tribute'. They were rated excellent. 'Flamenco', 'Heatwave II', 'Homestead 24F' and 'Super Sioux' were rated good. The other cultivars received a rating of fair, except for 'Longkeeper', which was considered to have poor overall fruit quality.

\section{$\mathrm{pH}$ and total soluble solids content}

Cultivars with the lowest $\mathrm{pH}$ (slightly below 4.0) were 'Florida 91', 'Homestead 24F', and 'Flamenco'. The cultivars with the highest pH were 'Skyway 687', 'Arkansas Traveler', and 'Longkeeper'. The cultivars with the highest total soluble solids (TSS) content were 'Heatwave II' and 'Flamenco', but they did not differ from 'Florida 91', 'Bella Rosa', 'Super Sioux', 'Longkeeper' and 'Arkansas Traveler'. The cultivar with the lowest TSS was 'Skyway 687' (Table 3).

\section{Discussion}

\section{Marketable fruit yield}

Local tomato yield data from recent years are not available, but the values in our study were comparable to, or higher than those reported in previous studies conducted by the NMSU Agricultural Experiment Station. Cultivars tested in conventional, main season production systems yielded an average of $37,212 \mathrm{~kg} / \mathrm{ha}$ of marketable medium sized fruit across four seasons from 1957 to 1960 (Jones, 1962) and $26,452 \mathrm{~kg} / \mathrm{ha}$ in 1978 (Cotter and Hilty, 1980). Mean yield values obtained for both the historic main-season and current mid-summer plantings were comparable to, or higher than, average fresh market tomato yields in the USA $(28,470 \mathrm{~kg} / \mathrm{ha}$ reported in 2014) (Lopez, 2017).

BCTV impact was below $10 \%$ during both seasons, indicating that mid-summer planting may be a suitable strategy for minimizing the risk of curly top in field tomatoes produced in the desert regions of the western USA. Yields may also have been impacted by begomovirus infection; however, the resistant cultivars 'Tribute' and 'Skyway 687' did not display significantly higher yield than the majority of cultivars, so the potential impact of possible begomovirus infection is unclear. Yield of the latest maturing cultivar ('Homestead') was the lowest in 2016, suggesting that its late maturity may also have been a contributing factor, because unripe fruit were unable to mature before the onset of cold weather. Producers will have less flexibility for the timing of planting, and increased vulnerability to early frost in the fall, with later maturing cultivars. It will be necessary to weigh the risks associated with cultivar selection for their climate area and cropping systems. Extension of the growing season using row covers is an option that could be considered.

Fruit cracking and BER were minor quality problems overall; however, these disorders were prevalent in 'Arkansas Traveler' and 'Homestead 24F' (data not presented). Reduced incidence in comparison with main-season crops was likely due to cooler conditions during late summer and early fall that reduced soil moisture fluctuations and favored more gradual fruit ripening. Fruit that remained in contact with the soil surface for prolonged periods were susceptible to rotting. This likely affected larger-fruited cultivars to a greater degree. The amount of fruit culled due to fruit rot was not determined; however, losses were more noticeable in 2017 when largerfruited cultivars were produced. Staking or trellising of plants could perhaps have avoided losses to rot. We do not consider fruit rot to have been associated with heat or water stress.

\section{Fruit set}

Putative heat-tolerant cultivars showed some variation for FS, but FS levels above $75 \%$ appeared to be sufficient to secure acceptable fruit loads. FS was only weakly correlated with yield $\left(R^{2}=0.29\right)$ and significant only at the 0.1 level $(P<0.09)$. Surprisingly, the HS susceptible checks 'Moneymaker' and 'Longkeeper' (Bita et al., 2011; Dane, 1991) displayed FS values comparable to those of the cultivars with the highest FS values. Periods of high-temperature stress capable of inducing blossom-drop were in evidence during both seasons and hotset hybrids did not appear to confer a distinct yield advantage over HS tolerant OP cultivars. Because it cannot be known how hot any specific summer will be, planting hot-set hybrids or HS tolerant open-pollinated cultivars in desert regions should continue to be considered an essential tool for managing risk.

\section{Curly top}

Curly top occurred at low incidence levels in both 2016 and 2017. It is possible, but unlikely, that overall populations of the insect vector were low during both seasons, and that there were too few host plants in the area to provide sufficient inoculum reservoirs. It is more likely that the number of insects had declined by the time of planting, thus reducing the incidence of curly top observed in our plots. Other researchers in southern NM have documented as much as $56 \%$ plant mortality due to BCTV in main-season plantings during an adverse year (Jones, 1962). Mid-summer planting, combined 
Table 1. Yield, FS, days to maturity, fruit weight, and overall quality of tomato cultivars grown in 2016 in Las Cruces, New Mexico.

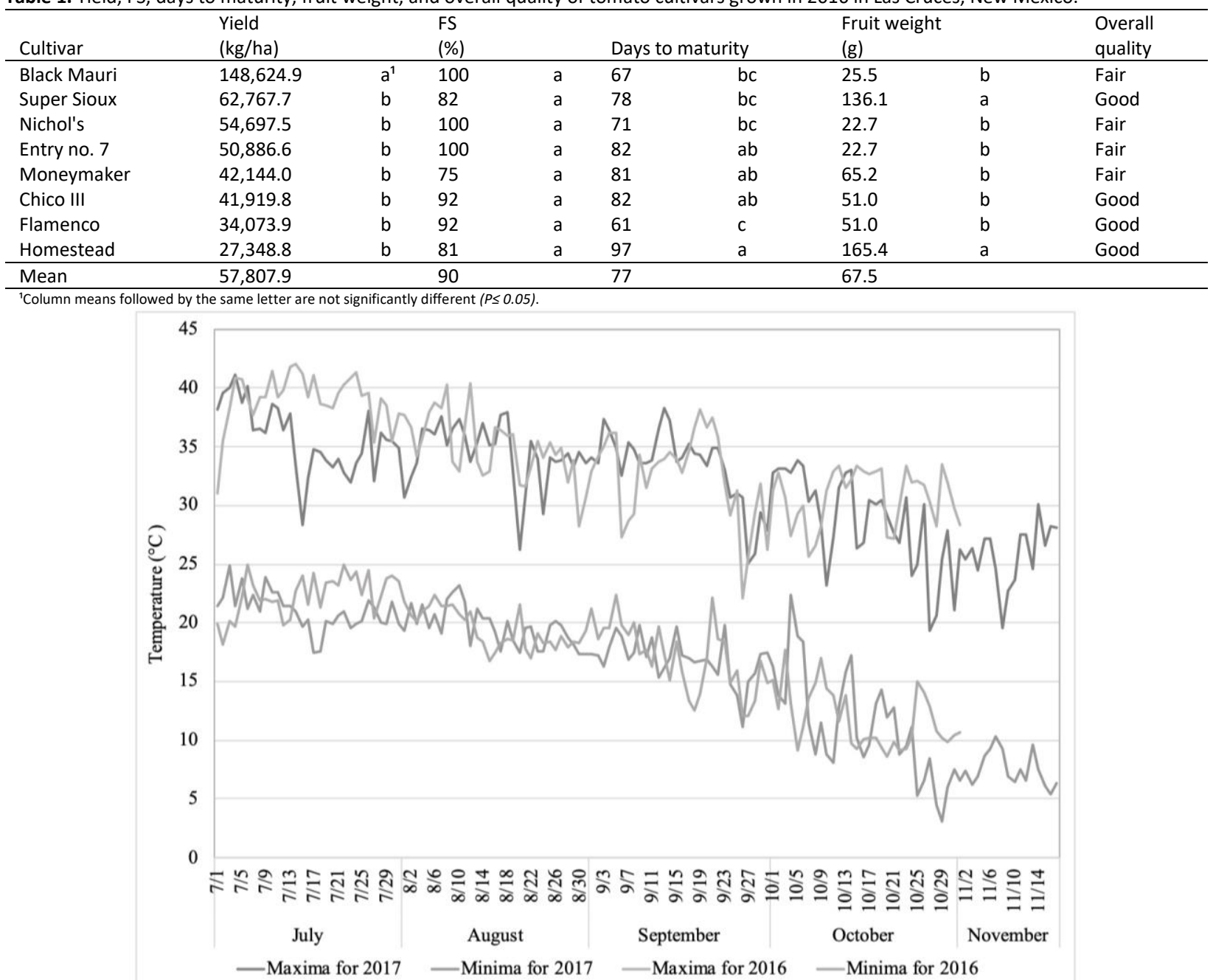

Fig 1. Temperature maxima and minima observed daily from July to mid-November in 2016 and 2017. Data obtained from the NMSU Campus Climate Center at Las Cruces, NM.

Table 2. Yield, FS, days to maturity, fruit weight, and overall quality of tomato cultivars grown in 2017 in Las Cruces, New Mexico.

\begin{tabular}{|c|c|c|c|c|c|c|c|c|c|}
\hline \multirow{2}{*}{$\begin{array}{l}\text { Cultivar } \\
\text { Flamenco }\end{array}$} & \multicolumn{2}{|l|}{$\begin{array}{l}\text { Yield } \\
\text { (kg/ha) }\end{array}$} & \multicolumn{2}{|l|}{$\begin{array}{l}\text { FS } \\
(\%)\end{array}$} & \multicolumn{2}{|c|}{ Days to maturity } & \multicolumn{2}{|c|}{$\begin{array}{l}\text { Fruit weight } \\
\text { (g) }\end{array}$} & \multirow{2}{*}{$\begin{array}{l}\text { Overall quality } \\
\text { Good }\end{array}$} \\
\hline & $76,666.2$ & $a^{1}$ & 100 & $\mathrm{a}$ & 79 & $\mathrm{~b}$ & 68.0 & $\mathrm{e}$ & \\
\hline Super Sioux & $57,163.4$ & $a b$ & 76 & $\mathrm{a}$ & 93 & a & 99.2 & de & Good \\
\hline Skyway 687 & $50,438.3$ & bc & 77 & $a$ & 91 & $\mathrm{a}$ & 309.0 & $a$ & Good \\
\hline Florida 91 & $43,264.9$ & bcd & 88 & a & 97 & $\mathrm{a}$ & 252.3 & $a b c$ & Excellent \\
\hline Heatwave II & $42,144.0$ & bcd & 77 & $\mathrm{a}$ & 90 & $\mathrm{a}$ & 164.4 & $\mathrm{~cd}$ & Fair \\
\hline Tribute & $41,919.8$ & bcd & 92 & a & 101 & $\mathrm{a}$ & 263.6 & $a b$ & Excellent \\
\hline Longkeeper & $32,056.3$ & bcd & 96 & a & 98 & $\mathrm{a}$ & 96.3 & de & Poor \\
\hline Arkansas Traveler & $31,383.8$ & $\mathrm{~cd}$ & 58 & a & 98 & $\mathrm{a}$ & 198.4 & $\mathrm{bc}$ & Fair \\
\hline Homestead 24F & $21,520.3$ & $d$ & 73 & a & 91 & a & 99.2 & de & Fair \\
\hline Bella Rosa & $21,296.2$ & d & 80 & $\mathrm{a}$ & 98 & $\mathrm{a}$ & 184.2 & $\mathrm{bcd}$ & Excellent \\
\hline Mean & $41,785.3$ & & 82 & & 94 & & 173.5 & & \\
\hline
\end{tabular}

${ }^{1}$ Column means followed by the same letter are not significantly different $(P \leq 0.05)$. 
Table 3. pH and TSS of late-season tomato cultivars grown in 2017 in Las Cruces, New Mexico.

\begin{tabular}{lllll}
\hline Cultivar & $\mathrm{pH}$ & & $\begin{array}{c}\text { TSS } \\
\left({ }^{\circ} \text { Brix }\right)\end{array}$ & \\
\hline Skyway 687 & 4.26 & $\mathrm{a}^{1}$ & 3.8 & $\mathrm{bc}$ \\
Arkansas Traveler & 4.23 & $\mathrm{ab}$ & 4.2 & $\mathrm{abc}$ \\
Longkeeper & 4.17 & $\mathrm{abc}$ & 4.6 & $\mathrm{ab}$ \\
Tribute $^{2}$ & 4.06 & $\mathrm{bcd}$ & 4.1 & $\mathrm{bc}$ \\
Super Sioux $^{2}$ & 4.06 & $\mathrm{bcd}$ & 4.5 & $\mathrm{abc}$ \\
Bella Rosa $^{2}$ & 4.03 & $\mathrm{~cd}$ & 4.7 & $\mathrm{ab}$ \\
Heatwave II & 4.01 & $\mathrm{~cd}$ & 5.0 & $\mathrm{a}$ \\
Flamenco & 3.97 & $\mathrm{~d}$ & 5.0 & $\mathrm{a}$ \\
Homestead 24F $^{2}$ & 3.96 & $\mathrm{~d}$ & 4.1 & $\mathrm{ac}$ \\
Florida 91 & 3.95 & $\mathrm{~d}$ & 4.4 & $\mathrm{abc}$ \\
\hline Mean & 4.07 & \multicolumn{5}{c}{4.4} & \\
\hline${ }^{1}$ Column means followed by the same letter are not significantly different $(P \leq 0.05)$. &
\end{tabular}

Table 4. Seed Source and growth habit of tomato cultivars tested in 2016 and 2017 at Las Cruces, New Mexico.

\begin{tabular}{|c|c|c|c|c|}
\hline Year & Cultivar & Seed Source & Growth Habit & Hybrid/ OP \\
\hline \multirow[t]{8}{*}{2016} & Black Mauri & Downright Natural & Indeterminate & OP \\
\hline & Chico III & Sustainable Seed & Determinate & OP \\
\hline & Entry no. $7^{1}$ & Downright Natural & - & unk. \\
\hline & Flamenco & Native Seeds/ SEARCH & Semi-determinate & OP \\
\hline & Homestead & Eden & Semi-determinate & OP \\
\hline & Moneymaker & Eden & Indeterminate & OP \\
\hline & Nichol's & Native Seeds/ SEARCH & Indeterminate & OP \\
\hline & Super Sioux & Sustainable Seed & Indeterminate & OP \\
\hline \multirow[t]{9}{*}{2017} & Arkansas Traveler & Tomato Growers Supply Company & Indeterminate & OP \\
\hline & Bella Rosa & Tomato Growers Supply Company & Determinate & Hybrid \\
\hline & Flamenco & Native Seeds/ SEARCH & Semi-Determinate & OP \\
\hline & Florida $91^{2}$ & Tomato Growers Supply Company & Determinate & Hybrid \\
\hline & Heatwave $\| I^{2}$ & Burpee \& Co. & Determinate & Hybrid \\
\hline & Homestead 24F & Tomato Growers Supply Company & Determinate & OP \\
\hline & Longkeeper & Burpee \& Co. & Indeterminate & $\mathrm{OP}$ \\
\hline & Super Sioux & A. P. Whaley Seed Company & Indeterminate & $\mathrm{OP}$ \\
\hline & Tribute & Tomato Growers Supply Company & Determinate & Hybrid \\
\hline
\end{tabular}

${ }^{1}$ Entry no. 7 was not the cultivar requested when ordered. Its true identify is unknown. ${ }^{2}$ Hot-set cultivars.

with good weed management at the field site, appeared to have effectively kept curly top infection levels low.

\section{Days to maturity}

Our study showed that mid-summer planting of early to midseason cultivars allows sufficient time for acceptable yield to develop before low fall temperatures limit production. The moderately negative correlation $\left(R^{2}=-0.44\right.$, N.S.) observed between days to maturity and yield was not unexpected because longer maturing varieties still had immature fruit at the final harvest date.

Cultivar maturity is an important factor for producers to consider as part of the late-planting strategy. Early maturing cultivars are more vulnerable to flowering during periods of excessive heat; however, their fruit will be more likely to mature before an early autumn freeze. Later maturing cultivars may have a shorter period in which they are exposed to heat stress during the flowering period, but many unripe fruit would be vulnerable to cold injury in the fall. Growers may also wish to consider providing protection during the fall season by adding row covers if the additional expense is warranted.

The tendency in our study for days to maturity to be longer than indicated in catalog descriptors may have to do with growth cessation in response to periods of extreme heat stress. For example, in 2017, there were 10 consecutive days in late June with a high temperature at or above $38^{\circ} \mathrm{C}$. That stress may have resulted in delayed growth during the seedling stage (prior to transplanting).

\section{Fruit weight}

The catalog description of 'Homestead 24F', stated 170 to 280 $\mathrm{g}$ fruit weight, but in our test, they averaged $99 \mathrm{~g}$. Likewise, the catalog description of 'Bella Rosa' stated that fruit weighed 280 to $340 \mathrm{~g}$, but we observed an average weight of only $184 \mathrm{~g}$ (Table 2). The fruit weights for 'Homestead 24F' and 'Bella Rosa' may have been reduced due to the impact of TYLCV infection.

There was a negative correlation between fruit weight and TSS $\left(R^{2}=-0.56, \quad P<0.01\right)$. This is consistent with other research-Georgelis et al. (2004) who also found fruit size negatively correlated with sugars.

Fruit size depends on factors other than the genotype, including plant spacing, soil fertility, and climatic conditions. Growers are able to manage some of these factors, so they should be able to produce medium-sized fruit for the fall market.

\section{Overall fruit quality}

The checks 'Super Sioux' and 'Flamenco', were rated as having good fruit quality during each year. Several other cultivars also had good ratings, and several had fair quality. The poor overall quality of 'Longkeeper' was not unexpected because it is a slow ripening cultivar selected for its prolonged storability 
(Pressey and Avants, 1982). Only three cultivars received an excellent rating: 'Florida 91', 'Tribute', and 'Bella Rosa'. Recommendations for cultivar selection should likely avoid those cultivars with less than good ratings because consumer expectations are for superior fruit quality at higher price points (Healy et al., 2017).

\section{pH and total soluble solids content}

The $\mathrm{pH}$ of fresh market tomatoes ranges between 4.0 and 4.5 (Korob, 2020). In this study, 8 out of 10 cultivars were within the anticipated range. The TSS content of fresh market tomatoes is expected to vary between 3.5 and $5.3^{\circ} \mathrm{Brix}$ (Kleinhenz and Bumgarner, 2013), and all cultivars in this study were within the that range. Cultivars rated excellent for overall fruit quality evaluations displayed corresponding acidity and soluble solids values close to that of the overall means for those traits, suggesting that the balance was important for overall quality perception. Tomato fruit flavor is related to individual preferences for the ratio, or balance, between the concentrations of acid and sugar (Stevens et al., 1979). Tomatoes in our study that were predicted to have the best flavor based on sugar and acid content were 'Florida 91', 'Flamenco', 'Heatwave II', 'Bella Rosa' and 'Super Sioux'. These cultivars also received good or excellent overall fruit quality ratings in our subjective tests.

\section{Materials and Methods}

\section{Plant materials}

We obtained organic certified seed of cultivars whose varietal descriptors included small or medium sized fruit and heat stress tolerance as attributes. We tested eight early to mid-late season, open-pollinated cultivars that produce small- or medium-sized fruit (larger than cherry tomatoes but smaller than large tomatoes) in the weight range of approximately 25 to $220 \mathrm{~g}$ in 2016 . Cherry cultivars were excluded, but both determinate and indeterminate types were included. We established that it was possible to produce acceptable yields of marketable fruit in 2016, so we extended the scope of our study to include additional open-pollinated and hybrid cultivars with somewhat larger fruit, in 2017. One small-fruited cultivar ('Flamenco') and one medium-fruited cultivar ('SuperSioux') served as check varieties during both years. The cultivars 'Moneymaker' and 'Longkeeper', reported in the literature as being heat-sensitive, were included as heatsusceptible checks in 2016 and 2017, respectively (Table 4).

During both years, seeds were planted in an Organic Review Institute Listed (OMRI) potting mix (Nature's Care, Scotts Miracle-Gro, Marysville, $\mathrm{OH}$ ) in plastic flats with "pony paks" (T. O. Plastics, Clearwater, MN) under an outdoor shade-cloth structure (fitted with $40 \%$ sun block cover). Flats were watered daily until the second true leaf was apparent. Seedlings were then transplanted to $10 \mathrm{~cm}$ plastic pots containing soil medium consisting of three parts potting mix and one part perlite. Plants were again placed under the shade-cloth and watered daily until transplanted to the field. Excess plants of all cultivars were held in reserve in case of failed transplanting.

Field plot preparation and management - 2016

The experimental site was at the Student Research and Education Gardens in Las Cruces, New Mexico (lat. $32^{\circ} 28^{\prime} 04.39^{\prime \prime}$ long. $106^{\circ} 75^{\prime} 88.71^{\prime \prime}$; elev. $1165 \mathrm{~m}$ ). The field is organic certified. The soil type is a Belen clay [Clayey over loamy, smectitic over mixed, superactive, calcareous, thermic Vertic Torrifluvents]. The 2016 planting followed beets (Beta vulgaris L.) in a field that was amended with $78,456 \mathrm{~kg} / \mathrm{ha}$ of steer manure incorporated approximately three months prior to planting. Seedlings were transplanted to the field at $60 \mathrm{~cm}$ spacing within the row, on a $102 \mathrm{~cm}$ center-to-center bed and furrow system on June 30, 2016. Transplants that did not survive transplanting were replaced. Plots were irrigated through the bed and furrow system as needed. Plants were not staked or trained. Weeds were managed by hand-hoeing as required.

In 2016, a Rhizoctonia solani infection was noted in adjacent bean (Phaseolus vulgaris L.) plots. Tomato plants thought to display infection upon inspection by a plant pathologist were removed from the plot and sampled for examination by the NMSU Plant Diagnostic Clinic (https://aces.nmsu.edu/ces/plantclinic/). The samples were confirmed to be infected by $R$. solani and the entire tomato (and bean) plots were treated with an OMRI approved fungicide (Double Nickel 55, Certis USA).

Field plot preparation, planting and management - 2017 In 2017, the planting followed Sudax (sorghum $\times$ Sudan grass) in soil amended with $2,242 \mathrm{~kg} / \mathrm{ha}$ of dried chicken manure pellets (4-2-2) obtained from The Farms Choice, Phoenix, AZ. Pellets were broadcast and incorporated approximately three months prior to planting. Seedlings were transplanted to the field at $60 \mathrm{~cm}$ spacing within the row, on a $102 \mathrm{~cm}$ center-tocenter bed and furrow system on July 14, 2017. Seedlings that did not survive transplanting were replaced. Plots were irrigated through the bed and furrow system as needed. Plants were not staked or trained. Weeds were managed by handhoeing as required.

In 2017, approximately $30 \%$ of the plants appeared to display symptoms associated with infection by a begomovirus. Tomato yellow mosaic virus (TYMV) and tomato yellow leaf curl virus (TYLCV) are within the begomovirus genus. Infected plants are characterized by chlorotic mottling, leaf distortion, stunted plants, decreased FS, and significant yield reduction (Polston et al., 1994). Tomato plants thought to display infection were sampled by the NMSU Plant Diagnostic Clinic (https://aces.nmsu.edu/ces/plantclinic/) and the samples tested positive for begomovirus. The virus is transmitted by whitefly (Bemisia tabaci) and through seed (Kil et al., 2016). We did not observe whiteflies in the field, so we assume that the pathogen was most likely transmitted from infected seed. Cultivars in this study with documented resistance to TYLCV were 'Skyway 687' and 'Tribute' (Vitalis Organic Seed, 2020; Sakata Seeds America, 2020).

\section{Traits measured - 2016}

The primary criteria used to assess cultivar suitability for midsummer planting were percent FS, total marketable fruit yield, and overall fruit quality. Percent FS was determined by tagging one random truss per plant at the onset of flowering, dividing the number of FS after two weeks by the number of flower buds originally on the truss, and multiplying by 100 . The total marketable fruit yield was determined from weekly harvests conducted from September until October 2016 (total 7 
7 harvests). Marketable fruit was defined as being free of cracking, blossom-end rot, disfiguration, and absence of disease, insect, or other physical damage. The individual fruit weights were measured from 30 fruit per plant. Overall fruit quality was subjectively evaluated by the authors. Coded samples were rated as excellent, good, fair, or poor for their prospective consumer appeal based on their appearance (size, color, and shape) texture, and flavor.

The number of days to maturity was also recorded so that it could be used in comparing varieties. The number of days to maturity was determined by calculating the number of days from the planting date (transplanted to field) until the day the first ripe fruit was picked.

\section{Traits measured - 2017}

The primary criteria used to assess cultivar suitability for midsummer planting were percent FS, total marketable fruit yield, and overall fruit quality. Percent FS was determined as described above. The total marketable fruit yield was determined from bi-weekly harvests from mid-September to mid-November (total 12 harvests). Marketable fruit was defined as described above. The individual fruit weights were measured from 15 fruit per plant. Overall fruit quality was subjectively evaluated by the authors. Coded samples were rated as described above.

Fruit $\mathrm{pH}$ and TSS were measured in 2017 to examine the relationship between the subjective overall fruit quality rating and well-established fruit quality traits: $\mathrm{pH}$, sugar, and acid content. For $\mathrm{pH}$ determination, groups of three fruit per cultivar were each made into a puree with a handheld mixer (Sensio Inc., Montreal, Canada) and tested for $\mathrm{pH}$ with a Checker portable pH meter (Hanna Instruments, Woonsocket, $\mathrm{RI})$. The fruit purees were frozen for a week, allowed to rise to room temperature $\left(19^{\circ} \mathrm{C}\right)$, and then centrifuged for $5 \mathrm{~min}$ at 1400 RPM $(373 \times g)$. Evaluation of total soluble solids content was determined by putting a few drops of the supernatant on a handheld refractometer (Model 2313; Atago Co. Ltd., Tokyo, Japan) and expressed as ${ }^{\circ}$ Brix.

The number of days to maturity was also recorded so that it could be used in comparing varieties. The number of days to maturity was determined by calculating the number of days from the planting date (transplanted to field) until the day the first ripe fruit was picked.

\section{Experimental design and statistical analysis}

A randomized complete block (RCB) design with two replications and three plants per plot was employed in 2016. In 2017, an RCB design with two replications and four plants per plot, with a border plant at the end of each plot, was used. In order to accommodate the number of varieties examined, and maintain precision in trait data sampling, we minimized the number of replications in the planting design but maintained multiple observations for determination of each plot (replicate) mean as implemented in organic tomato variety trials by Healy et al. (2017).

Results were analyzed with cultivars as treatments using the General Linear Model (PROC GLM) procedure of SAS 9.4 for Windows (SAS Institute, 2008). Correlations between yield and trait data were determined using the SAS analysis, PROC CORR. Spearman correlations were considered significant at $(P<0.05)$.

\section{Conclusions}

Mid-summer planting can be a successful strategy for supplying fresh organic tomatoes to the late season market in the Desert Southwest below 1524 m elevation. We observed considerable variation among the cultivars producing small and medium fruit for yield, FS, and fruit quality. Our findings suggest that FS in most heat tolerant tomato cultivars planted in mid-summer is sufficient to provide acceptable yields of good quality fruit. Minimal curly top was observed in the field plots during each year-supporting the hypothesis that midsummer planting can result in avoidance of the disease.

None of the tested cultivars showed all of the desired characteristics for FS, marketable yield, overall quality, and the desired characteristics of high acid and sugar content. Black Mauri exhibited high yield, but its fruit type (black) is relatively unknown, and it did not receive a favorable overall quality rating. The mid-season check OP cultivar 'Super Sioux' displayed both good yields and good fruit quality over both years. 'Super Sioux' is recommended as a suitable cultivar for the mid-summer planting strategy. The early maturing check cultivar 'Flamenco, had inconsistent yield, but maintained good overall fruit quality ratings across years. Flamenco is recommended for further evaluation as an early maturing, small-fruited cultivar, with good fruit quality. 'Florida 91' and 'Skyway 687' are producers of medium sized and large fruit, respectively. They demonstrated above average yield and received excellent or good overall fruit quality ratings, respectively. 'Tribute' received an excellent rating for overall fruit quality, but it is late maturing, and presents added risk if an early freeze were to occur. Hybrid hot-set cultivars ('Florida 91' and 'Heatwave II') did not appear to confer additional advantage for FS over other heat-tolerant varieties. 'Arkansas Traveler' and 'Homestead 24F' are not recommended for production because of lower than average FS, higher than average incidence of fruit cracking, and low yield.

Additional risk management may be achieved by planting both early and mid-season heat tolerant cultivars on multiple planting dates during mid-summer.

\section{Acknowledgements}

Research was part of an undergraduate independent study undertaken by the senior author at the Student Research and Education Gardens. Special thanks to Dr. Geno Picchioni for his advice and the Cropping Systems Research Innovation Program and the Department of Plant and Environmental Sciences for providing the opportunity to use needed facilities. We thank Dr. Lois Grant and Dr. Stephanie Walker for reviewing an earlier copy of the manuscript. We also wish to acknowledge Mr. Anthony Aranda and the Fabian Garcia Science Center farm crew for their able assistance with field operations.

\section{References}

Baskins S, Bond J, Minor T (2019) Unpacking the growth in per capita availability of fresh market tomatoes. VGS-19C-01. USDA, ERS. 
Bita CE, Zenoni S, Vriezen WH, Mariani C, Pezzotti M, Gerats T (2011) Temperature stress differentially modulates Itranscription in meiotic anthers of heat-tolerant and heatsensitive tomato plants. BMC Genomics. 12:384.

Blickenstaff CC, Traveller D (1979) Factors affecting curly top damage to sugarbeets and beans in southern Idaho, 191977. Science and Education Administration, Agricultural Reviews and Manuals, Western Series [No. 8]. Oakland, CA: USDA-ARS.

Chen L-F, Brannigan K, Clark R, Gilbertson RL (2009) Characterization of curtoviruses associated with curly top disease of tomato in California and monitoring for these viruses in beet leafhoppers. Plant Dis. 94:99-108.

Chen L-F, Gilbertson RL (2016) Transmission of curtoviruses (beet curly top virus) by the beet leafhopper (Circulifer tenellus). In: Vector-Mediated Transmission of Plant Pathogens (ed JK Brown), Amer Phytopath Soc Press, St. Paul, MN.

Cotter DJ (1978) Tomato fruit set, temperature, and yield relationships in an arid climate. New Mex Agr Exp St R 371:18.

Cotter DJ, Hilty J (1980) Cultivar and planting date effects on tomato yields and quality. New Mex Agr Exp St R 414:3-8.

Creamer R, Carpenter J, Rascon J (2003) Incidence of the beet leafhopper, Circulifer tenellus (Homoptera: Cicadellidae) in New Mexico chile. Southwest Entomol. 28(3):177-182.

Dane F, Hunter AG, Chambliss OL (1991) Fruit set, pollen fertility and combining ability of selected tomato genotypes under high-temperature field conditions. J Am Soc Hortic Sci. 116:906-10.

Fontenot K (2016) Growing great home garden tomatoes. Louisiana Agric. 59(2):18-19.

Georgelis N, Scott JW, Baldwin EA (2004) Relationship of tomato fruit sugar concentration with physical and chemical traits and linkage of RAPD markers. J Am Soc Hortic Sci. 129(6):839-845.

Goldberg NP (2001) Curly top virus. New Mex Coop Ext S G H106.

Healy GK, Emerson FJ, Dawson JC (2017) Tomato variety trials for productivity and quality in organic hoop house versus open field management. Renew Agr Food Syst 32(6):562572.

Heflebower R, Reid C, Winward D (2012) Controlling curly top of tomato using resistant varieties and row covers. University Extension. J Nat Assoc County Agr Agents. 5:2.

Horneburg B, Myers J (2012) Tomato: Breeding for improved disease resistance in fresh market and home garden varieties. In: Organic Crop Breeding (eds. ET Lammerts van Bueren and JR Myers),John Wiley \& Sons Ltd, Chichester, UK.

Jones MB (1962) Performance of tomato varieties. New Mex Agr Res S B 463.

Kaiser C, Ernst M (2016) Organic Tomatoes. Center for Crop Diversification Crop Profile. College of Agriculture, Food, and the Environment, University of Kentucky, Lexington, KY, USA.

Kemble JM, Tyson TW, Curtis, LM (2004) Guide to commercial staked tomato production in Alabama. Ala Coop Ext Sys Circ ANR. 1156.

Kil E, Kim S, Lee Y, Byun H, Park J, Seo H, Kim C, Shim J, Lee K, Choi H, Lee S (2016) Tomato Yellow Leaf Curl Virus (TYLCVIL): A seed-transmissible geminivirus in tomatoes. Sci RepUK. 6:19013.
Kleinhenz MD, Bumgarner NR (2013) Using brix as an indicator of vegetable quality: linking measured values to crop management. Ohio State Coop Ext Circ HYG-1651.

Korob S (2020) Managing tomato taste. Yara North America Inc., Tampa, FL. http://www.yara.us/agriculture/crops/tomato/quality/mana ging-tomato-taste/ (accessed 10 February 2020).

Lehnhoff E, and Creamer R (2020) Prediction of early season beet leafhopper populations in southern New Mexico. Plant Health Prog 21:71-76.

Lopez JA (2017) A demand analysis for fresh tomatoes in the Dallas/Fort Worth grocery market. Tex J Agr Nat Res. 30:1637.

Matas AJ, López-Casado G, Cuartero J, Heredia A (2005) Relative humidity and temperature modify the mechanical properties of isolated tomato fruit cuticles. Am J Bot. 92:462-468.

Mills L, Johnson W (1988) Common tomato disorders under desert conditions. FS-88-60. University of Nevada, Reno, Extension, University of Nevada, Reno, NV.

NM Climate Center (2018) Climate in New Mexico. New Mexico State University. https://weather.nmsu.edu/ (accessed 18 June 2018).

Peet MM, Bartholomew M (1996) Effect of night temperature on pollen characteristics, growth and fruit set in tomato (Lycopersicon esculentum mill). J Am Soc Hortic Sci. 121:514519.

Polston JE, McGovern RJ, Stansly PA (1994) Tomato yellow leaf curl virus. Fla Coop Ext Ser Circ1143.

Pressey R, Avants JK (1982) Pectic enzymes in 'LongKeeper' tomatoes. HortScience.17:398-400.

Sakata Seeds America (2020) Tribute [Sales Sheet] https://sakatavegetables.com/wpcontent/uploads/2017/07/SALESSHEET-CM-348.pdf. (accessed 3/4/20)

SAS Institute, Inc. (2008) SAS system. Version 9.4, SAS Institute, Inc. Cary, NC.

Smith C (2016) Yard \& garden: tomatoes are challenge to grow in hot New Mexico. Las Cruces Sun-News. https://www.lcsunnews.com/story/life/sunlife/2016/06/26/yard-gardentomatoes-challenge-grow-hot-new-mexico/86038730/ (accessed 10 February 2020).

Stevens MA, Kader AA, Albright M (1979) Potential for increasing tomato flavor via increased sugar and acid content. J Am Soc Hortic Sci. 104(1):40-42.

Vitalis Organic Seeds (2020) Skyway 687 Variety descriptor. https://usa.vitalisorganic.com/products-and-services/ourproducts/Tomatoes/Skyway\%20687\%20F1 (accessed 9/11/2020)

Walker S (2014) Home vegetable gardening in New Mexico. New Mex Coop Ext S C. 457. 